\title{
A comprehensive bibliography on effectiveness measurement of manufacturing systems
}

\author{
Sanjeev Goyal and Sandeep Grover
}

Department of Mechanical Engineering, YMCA University of Science \& Technology, Faridabad, India

\begin{tabular}{|c|c|}
\hline ART I C LE I NFO & ABSTRACT \\
\hline $\begin{array}{l}\text { Article history: } \\
\text { Received } 25 \text { February } 2012 \\
\text { Accepted March } 232012 \\
\text { Available online } \\
24 \text { March } 2012 \\
\text { Keywords: } \\
\text { Effectiveness Measurement } \\
\text { Manufacturing Systems } \\
\text { Advanced Manufacturing Systems } \\
\text { MADM Techniques }\end{array}$ & $\begin{array}{l}\text { Globalization has put fierce competition for manufacturing managers in terms of flexibility, } \\
\text { smaller lead times, competitive costs, etc. To attain these capabilities, manufacturing managers } \\
\text { are taking heedless decisions for investing in advanced manufacturing technologies, without } \\
\text { measuring their actual effectiveness for their organisations. There is a need to measure the } \\
\text { effectiveness of manufacturing systems to make better future policies and investment planning. } \\
\text { This paper provides a comprehensive bibliography on the techniques and their rationale in the } \\
\text { effectiveness measurement of advanced manufacturing systems. The paper cites } 265 \text { articles from } \\
\text { a variety of published sources. The list contains published research mainly from } 1990 \text { to } 2012 \text { and } \\
\text { a selected published work prior to } 1990 \text {. }\end{array}$ \\
\hline
\end{tabular}

\section{Introduction}

Measuring effectiveness of a manufacturing system is becoming an increasing concern for both academics and practitioners (Neely, et al., 2000; Neely A. D., 1998). Effectiveness of manufacturing system is defined as the production of desired output to meet customer requirements (Greshwin, Manufacturing Systems Engineering, 1994). Effectiveness is the ratio of actual output to the reference output. The starting point for making the measurement is to understand the difference between the efficient manufacturing system established by Western manufacturing companies and effective manufacturing systems introduced by Japanese car manufacturers (See Table 1) (Garside, 1999).

Observing the success of Japanese manufacturers, all manufacturing companies want to make their system effective by adopting new technologies like TQM, JIT, Lean Manufacturing, Automation in Manufacturing etc. These technologies although improves productivity substantially, yet due to their high input cost and complex implementation process, managers feel hesitant to adopt them. Moreover managers are afraid seeing the risk factor of investing huge amount of money without knowing the actual impact on output in their manufacturing environment.

\footnotetext{
* Corresponding author. Tel: +919582355994

E-mail: goyal.sanjeev@hotmail.com (S. Goyal)

C) 2012 Growing Science Ltd. All rights reserved. doi: $10.5267 /$ j.ijiec.2012.03.009
} 
Table 1

Comparison of efficient and effective manufacturing Systems

\begin{tabular}{ll}
\hline Efficient & Effective \\
\hline Traditional Plant & Flexible Automation \\
Functional Layout & Cells layout for material flow \\
Slow Changeovers & Rapid Changeovers \\
Batch size is large with long runs & Cost effective batch size \\
Maximizes machine utilization & Manufacture as per the need \\
Planned inventory buffers & Minimized inventory level \\
Long lead times & Shrunken lead time \\
Make to forecast & Make to order \\
Operations are difficult to handle & Manageable production \\
Overheads are high & Low overheads \\
High Production cost & Low Production cost \\
Customer concentrated & Reactive product readiness \\
Poor ownership of quality & Good ownership of quality \\
Poor schedule observance & Good schedule observance \\
\hline
\end{tabular}

The reasons for this is the inadequate effectiveness measurement models, which rationalise the decision making process and gives confidence to the managers by helping them to know what to invest, how to invest and where to invest. The famous quote in management is that "one which can't measure cannot manage". The process of deciding which measures of effectiveness for manufacturing system to adopt is a valuable one, not least because it pushes managers to be very specific about their priorities and the relationship among them, thereby identifying, and offering an opportunity to resolve, any hidden differences of opinion. The limitations of traditional measuring systems based on financial terms have been widely reported in the literature. The Measurement model should be simple, cognitive and objective. It should provide continuous improvement to the system. Widespread interest in this topic, however, is relatively recent. European Foundation for Quality Management's Business Excellence Model (see Fig. 1.) is an effectiveness measurement model. This consists of two distinct subsets of factors, broadly classified as enablers and results. In this, enablers are the levers that management can pull to deliver future results. One of the weaknesses of this, the terms used in this framework are so wide, that a number of models can be derived under each factor.

\begin{tabular}{|c|c|c|c|c|}
\hline \multicolumn{3}{|l|}{ Enablers } & \multicolumn{2}{|l|}{ Results } \\
\hline \multirow{3}{*}{ Leadership } & People & \multirow{3}{*}{ Processes } & People Results & \multirow{3}{*}{$\begin{array}{l}\text { Key } \\
\text { Performance } \\
\text { Results }\end{array}$} \\
\hline & Policy \& Strategy & & Customer Results & \\
\hline & $\begin{array}{l}\text { Partnerships } \quad \& \\
\text { Resources }\end{array}$ & & Society Results & \\
\hline
\end{tabular}

Fig. 1. European Foundation for Quality Management's Business Excellence Model

Wisner and Fawcett (1991) proposed a nine point process for measurement model design (see Fig. 2.) and emphasized that measurement model should be continuously updated seeing the current competition environment. At the end of the 1980s, world markets underwent a lot of change, including the implementation of new manufacturing technologies, and new production management philosophies. These changes have shown up the limitations of traditional performance measurement systems, as well as the need for new systems to be developed.

From the literature survey, it is evident that researchers have started using non-financial methods along with financial methods which are better suited for rating the performance of the manufacturing process on the basis of company's competitive priorities, such as the achievement of the levels of quality 
agreed with the customer, the reliability of delivery, and/or flexibility. Various researchers have tried to model the measurement of effectiveness of a manufacturing system by identifying various critical factors and prioritizing them by using various decision making techniques (Yang, Chuang, \& Huang, 2009; Jain et al., 2011; Ghalayini et al., 1997; Leong et al., 1990). The common limitation among these models is that, either they do not have considered the interrelationships among critical factors at all or at the most in hierarchal way. Even researchers have tried to find the overall effectiveness index by simply multiplying the weights of the factors with the company's performance for that particular factor, by doing this, they straightway, rule out any interrelationships among the factors, which is rather unusual. So, there is a need to develop an effectiveness model that considers the inter relationship among the factor at the inner and outer level, with the provision of feedback and gives overall effectiveness index. This effectiveness model should follow the ' 9 ' point process described in Fig. 2. The model will help managers benchmark the manufacturing system's effectiveness with their peers and can continuously improve their system to become the best in the market. This will further helps managers analyse the importance of one factor and effect of that particular factor over the system's overall effectiveness and accordingly managers can prioritize their policies and investments to get the maximum competitive advantage.

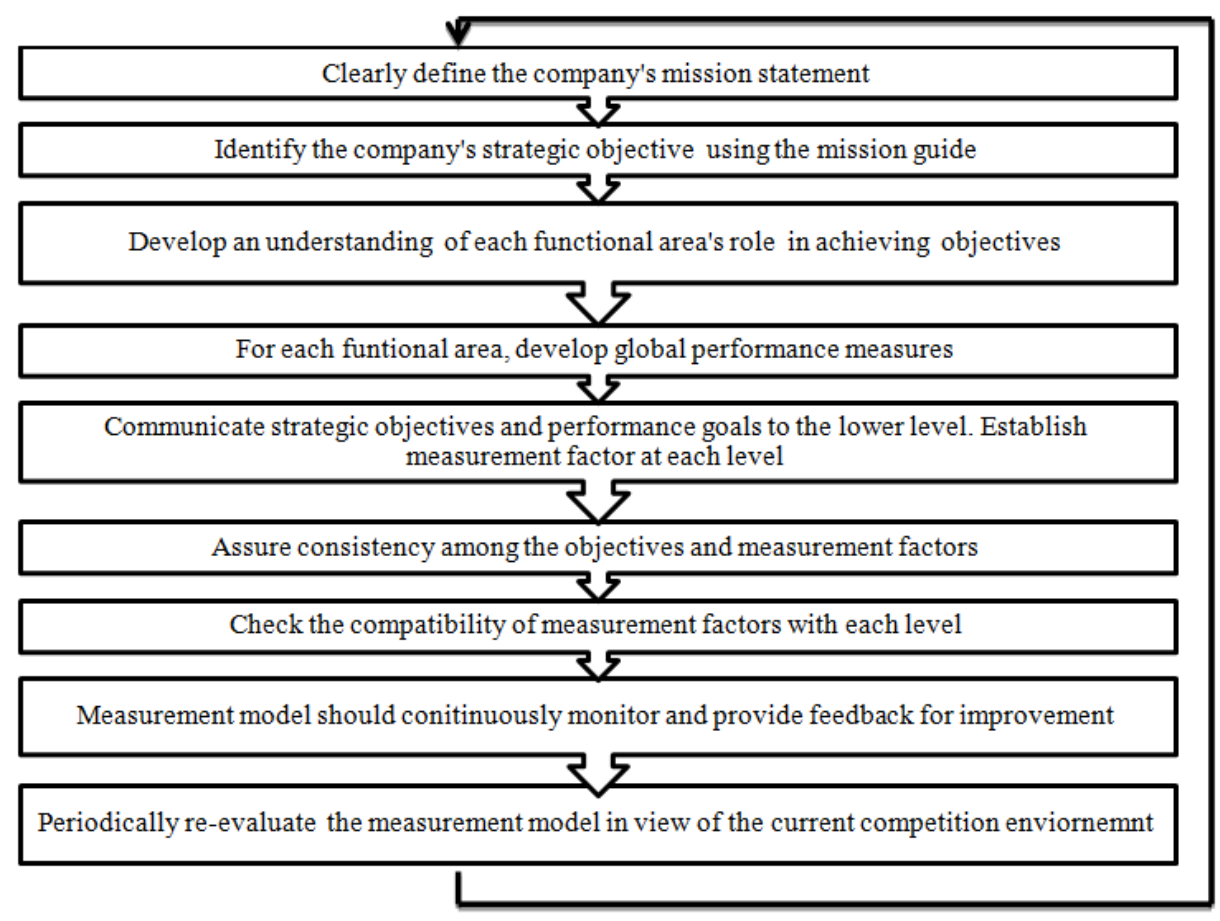

Fig. 2. '9' Point Process for Effectiveness Measurement Model

\section{Manufacturing effectiveness-the need for change}

Effective manufacturing system is the foundation for achieving competitive advantage and business excellence. Globalization has put managers under fierce competition to look for new technologies, which enable their manufacturing systems to produce high quality parts at the minimum cost. Garside (1999) identified the critical factors for an effective manufacturing system:

- Recognises cost effective production methods

- Develops manufacturing cells according to the business need

- Creates team environment for self-directed work groups

- Provides methods for investment appraisal

- Plans for man power requirement 
- Provides expansion, machine, process, routing and volume flexibility

- Provides methods to determine actual cost for manufacturing

- Introduces methods to control material and tooling

- Recognises the competition objectives and embed them into operational processes

- Establish quality control at each step of manufacturing

- Evaluates the customer satisfaction

- Integrates process design with the product introduction process

- Improves product reliability by re-designing the manufacturing process and assembly

- Assist the supplier base according to the competition objective

- Provides the provisions for feedback and continuous improvement

To attain these capabilities, manufacturing systems should be redesign to meet customer quality, delivery commitments and manage resources. In the past, organisations had only two general production alternatives available: line, or continuous flow, organised around products; and job-shop flow, organised around products; and job shop flow, organised around equipment groupings like milling machines and lathes. The disadvantage of the job-shop alternative is high work-in-process (WIP) inventories. The disadvantage of continuous process is difficulty of changing over from one product to another. These requirements have brought a new category of advanced manufacturing systems, in which the systems aspect of the manufacturing processes and the integration functions are the essential features. Many new acronyms used to describe the new aspects reflect this system aspect: JIT (just-in-time), CIM (computer-integrated-manufacturing), and FMS (flexible manufacturing system). This development has resulted in a quantum leap from a functional workshop to a flow-based, cellular manufacturing.

\subsection{What are AMS?}

A high technology development in computing and microelectronics, designed to enhance manufacturing capabilities. Advanced manufacturing technologies are used in all areas of manufacturing, including design, control, fabrication, and assembly. This family of technologies includes robotics, computer-aided design (CAD), computer-aided engineering (CAE), MRP II, automated materials handling systems, electronic data interchange (EDI), computer-integrated manufacturing (CIM) systems, flexible manufacturing systems, and group technology. The system, which is formed from these technologies, is known as advanced manufacturing system. Error! Reference source not found.An AMS typically involves (Parthasarathy \& Sethi, 1990):

- A computer aided design system for developing and storing designs;

- A Computer aided manufacturing system that translates design information for manufacturing products; and controls material flow, tooling and testing;

- An automated storage and retrieval system for delivery/pick up of parts between machines and storage; and

- A supervisory computer that integrates all

An AMS integrates the information system, the manufacturing system, and the internal distribution system of the firm. AMS eliminates the need to buy different equipment for variety of products by providing its two distinctive characteristics: flexibility \& integration. It offers manufacturing cells with capability of processing variety of parts. In this way, it helps to reduce man \& machine, yet maintaining production levels. AMS offers many benefits: lower work-in-process, higher product quality, increase responsiveness to changing demands, and increased productivity. Though these benefits are very lucrative, there have not been many successful AMS.

\subsection{Effectiveness of AMS}

AMS provides greater choice of design variations that complicates the design process. Traditional manufacturing technologies predominantly enhance process efficiency and workers' physical capabilities through rigid and mechanized design (Hirschhorn, 1984) whereas AMS works on 
improving overall effectiveness of a manufacturing system (Choobineh, 1986; Kaplan, Must CIM be Justified by Faith Alone, 1986). Advantages are many but still, 50 to $75 \%$ adoption of AMS fail (Abdel-Kader \& Dugdale, 2001). The failure of effective AMS has been associated with variety of problems:

- Implementation problems: Zammuto \& O'Connor (1992) list the various problems arising from a lack of understanding of AMS and how these problems affect the implementation of such a system. Typical problems include implementation of AMS in a manner that does not support flexibility and management who are not willing to change their style and culture. A large number of authors have targeted this problem and have tried to provide the better solutions. The major contributions are: Attaran, 1989; Badiru, 1990; Baldwin, et al., 2002; Baldwin, et al., 1995; Beatty, 1990; Boyer, 1994; Boyer, et al., 1996; Burcher, et al., 1999; Chen, et al., 1994; Chen, et al., 1996; Co, et al., 1998; Costa, et al., 2009; Dangayach, et al., 2005; Dangayach, et al., 2003; Dangayach, et al., 2004; David, et al., 1996; Dean, et al., 1990; Dimnik, et al., 1993; Efstathiades, et al., 1999; Frohlich, 1998; Fulton, et al., 2010; Ghani, et al., 2002; Kunnathar, 2000; Machuca, et al., 2004; McDermott, et al., 1999; Mital, 1999; Naik, et al., 1992; Percival, 2004; Rahman, 2008; Raj, et al., 2007; Raj, et al., 2008; Raj, et al., 2010; Ramamurthy, 1995; Roth, et al., 1991; Saberi, et al., 2010; Sambasivarao, et al., 1994; Sa' nchez, 1996; Schroder, et al., 1999; Shani, et al., 1992; Singh, et al., 2007; Small, et al., 1997; Sohal, et al., 2001; Sohal, 1996; Thomas , et al., 2007; Udo, et al., 1996; Voss, 1988; Yusuff, et al., 2004; Zairi, 1998; Zhao, et al., 1997.

- Evaluation/ Justification Problems: Traditional financial methods are not adequate as AMS offers intangible benefits along with tangible. If these intangible benefits are not quantified during the appraisal of the technology, then they will appear as unexplained variances. This will force managers to refuse the investments in AMS that could be beneficial to the firm (Small \& Chen, Investment Justification of Advanced manufacturing Technology: An Empirical Analysis, 1995). The main hurdle in adopting AMS is the non-availability of proper justification methods. Researchers have put forward a number of justification methods based upon objective and subjective benefits by using different decision making techniques and also highlighted the need for subjective justification methods. The representative ones are: Abdel-Kader, et al., 2001; Agarwal, 1997; Boyer, et al., 1997; Canada, et al., 1989; Canada, et al., 1990; Chan, et al., 2001; Choobineh, 1986; Datta, et al., 1992; Hynek, et al., 2007; Kaplan, 1986; Karsak, et al., 2001; Kumar, et al., 1996; Marri, et al., 2006; Meredith, et al., 1990; Meredith, et al., 1986; Naik, et al., 1992; Ordoobadi, et al., 2001; Primrose, 1991; Sambasivarao, et al., 1997; Slagmulder, et al., 1992; Small, 2006; Stainer, et al., 1996; Zammuto, et al., 1992.

- $\quad$ Selection Problems: Selecting a suitable AMS is an important issue on operations managers when making capital investment decisions to improve their manufacturing performance (Chuu, 2009). Furthermore, the rapid growth of the AMS industry is now creating problem in new directions. Prospective firms now face the situation of having to make a decision among several AMS, all of which are capable of performing a specific task. The development and use of appropriate assessment approaches are crucial to ensuring that the analysis of each AMT project considers all benefits and costs (Small \& Chen, Investment Justification of Advanced manufacturing Technology: An Empirical Analysis, 1995). The representing work of researchers in the field of AMS selection is as: Agrawal, et al., 1991; Bhangle, et al., 2004; Bozdag - et al., 2003; Braglia, et al., 2010; Chu, et al., 2003; Chuu, 2009; Karsak, et al., 2002; Kumar, et al., 2010; Luong, 1998; Rao, et al., 2006; Sambasivarao, et al., 1995; Sarkis, 1997; Yurdakul, 2004.

From the literature survey of major publications from 1990 to 2012 on AMS Effectiveness, it is clear that AMS implementation is the most important factor for effectiveness as most of the publications are directed to this factor and the second important factor for effectiveness comes out to be justification. This should be agreeable because if we successfully initiate, plan \& 
execute, our projects will illustrate greater results. Fig. 3 presents the \%age contribution of critical factors in AMS effectiveness measurement.

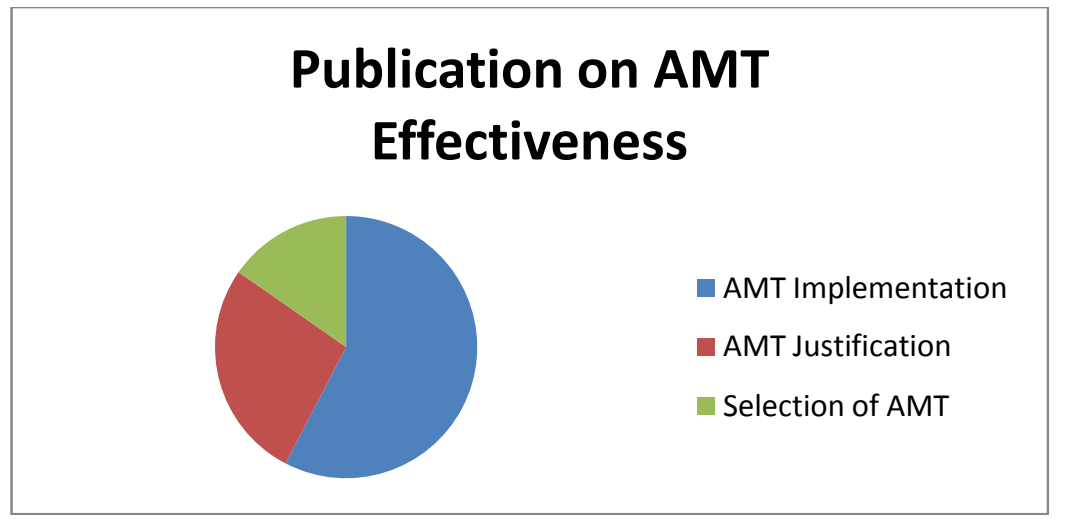

Fig. 3. \%age contribution of major factors in AMS effectiveness measurement

The main drawback in cultivating all the benefits of AMS is the non-availability of proper and acceptable methods for the effectiveness of AMS (Chan et al., 2001). It will be in great interest to the manufacturing managers to have models on the effectiveness of AMS that address the issues of implementation, justification and selection while quantifying the intangible factors and giving an overall single numerical index. This work is now possible with the advancements in Multi attribute Decision Making (MADM) techniques and Fuzzy Logic. The major MADM techniques and the corresponding name of the developers are listed in Table 2.

\section{Table 2}

Historical Development of MADM Techniques

\begin{tabular}{|c|c|c|}
\hline S.No. & MADM Technique & Developer \\
\hline 1. & Utility & (Bernoulli, 1738) \\
\hline 2. & Theory of games and economic behaviours & (Neumann \& Morgenstern, 1947) \\
\hline 3. & Choquet integral & (Choquet, 1953) \\
\hline 4. & Fuzzy Set & (Zadeh, 1965) \\
\hline 5. & ELECTRE methods & (Roy, 1968) \\
\hline 6. & $\mathrm{DM}$ in fuzzy environment & (Bellman \& Zadeh, 1970) \\
\hline 7. & ELECTRE I & (Roy, 1971) \\
\hline 8. & AHP & (Saaty, 1972) \\
\hline 9. & MADM & (Keeney \& Raiffa, 1976) \\
\hline 10. & ELECTRE II & (Roy, 1976). \\
\hline 11. & Fuzzy integral evaluation & (Sugeno, 1974) \\
\hline 12. & ELECTRE III, IV & (Roy, 1978) \\
\hline 13. & TOPSIS & (Hwang \& Yoon, 1981) \\
\hline 14. & GREY & (Deng, 1982) \\
\hline 15. & Rough Sets & (Pawlak, 1982) \\
\hline 16. & PROMETHEE I, II, III \& IV & (Brans, et al., 1984) \\
\hline 17. & FMADM & (Sakawa, 1984) \\
\hline 18. & Dynamic weights AHP & (Saaty, 1992) \\
\hline 19. & Rough Set MADM & (Pawlak \& Slowinski, 1994) \\
\hline 20. & TOPSIS for MODM & (Hwang, et al., 1996) \\
\hline 21. & Fuzzy neural network dynamic MADM & Hashiyama et al. \\
\hline 22. & Non independent ANP & (Saaty, 1996) \\
\hline 23. & Dynamic weights with habitual domain & (Tzeng, et al., 1997) \\
\hline 24. & Fuzzy measures and habitual domain & (Chen \& Tzeng, 1999) \\
\hline 25. & VIKOR & (Opricovic, 1998) \\
\hline
\end{tabular}

Some of the MADM techniques that will be helpful in measuring effectiveness of the AMS are discussed below briefly. 
Analytical Network Process: ANP is a general form of AHP. AHP was first proposed by Saaty (1980a \& 1980b). ANP simultaneously takes into account both feedback and dependence There are multiple applications of ANP in many areas. Some representative ones are: product mix planning in semiconductor fabricator (Chung, et al., 2005); modeling the metrics of lean, agile and leagile supply chain (Agrawal, et al., 2006); manufacturing system evaluation in wafer industry (Yang, et al., 2009); purchasing decisions (Ustun \& Demirtas, 2009); supplier selection (Lang, et al., 2009); prioritizing success factors in manufacturing enterprises (Karpak \& Topcu, 2010); customer relationship management (Oztaysi, et al., 2011).

Total Interpretive Structural Modeling (TISM): Total Interpretative Structural Modeling (TISM) approach is extension of the well-established ISM approach (Nasim, 2011). ISM approach metamorphoses nebulous models of systems into unambiguous, manifest models, useful for many purposes (Sage, 1977). Warfield $(1973,1994,1999)$ developed the philosophical basis and conceptualize the analytical details of the ISM process. Saxena et al. (2006) applied it in conjunction with other modeling methodologies in the context of energy conservation policy. There are multiple other applications of ISM in many areas; some representative ones are: knowledge management (Singh et al., 2003), supply chain management (Agarwal et al., 2007), flexible manufacturing systems (Raj et al., 2008), decision support systems (Hansen et al., 1979), waste management (Sharma and Sushil, 1995), vendor selection (Mandal and Deshmukh, 1994), knowledge management (Singh et al., 2003), product design (Lin et al., 2006), supply chain management (Agarwal et al., 2007), decision making (Lee, 2008), value chain management (Mohammed et al., 2008) and so on.

Graph Theoretic and Matrix Approach (GTMA): Graph theoretic and matrix model consists of digraph representation, matrix representation and permanent representation. It is a powerful technique to calculate single numerical index for evaluation of critical factors pertaining to a problem of any field. Grover, Agrawal and Khan $(2004,2006)$ applied it for TQM evaluation of an industry and to find the role of human factors in TQM. There are multiple other applications of GTA in many areas; some representative ones are: robot selection (Agrawal et al., 1991), failure cause analysis (Gandhi \& Agrawal, 1996), development of maintainability index for mechanical systems (Wani \& Gandhi , 1999), machinability evaluation of work materials (Rao \& Gandhi, 2002), capability envelop of a machining process (Huang \& Yip-Hoi, 2003), performance evaluation of TQM in Indian industries (Kulkarni, 2005), selection, identification and comparison of industrial robots (Rao \& Padmanabhan, 2006), to optimize single-product flow-line configurations of RMS (Dou et al., 2009) and so on.

Techniques for Order Preference by Similarity to Ideal Solution (TOPSIS): TOPSIS method was proposed by Hwang \& Yoon in 1981. This method is used to determine the best alternative based on the compromise solution. The compromise solution can be termed as the solution with the smallest Euclidean distance from the positive ideal solution and the farthest distance from the negative ideal solution. The positive ideal solution is regarded as the solution when all the attributes reach its maximum value and the negative ideal solution is termed as the solution when all its attributes reach the minimum level. So, TOPSIS method not only gives the solution closest to the optimal, but farthest from the inferior.

Grey Relational Analysis (GRA): During decision making process, the decision makers try to gather as much information as possible through surveys, investigations, sampling, etc., so as to reach the aspired decision, but obtaining all the information remains impossibility; therefore decisions are usually made in grey process, i.e. without complete information. This is where GRA, finds application in solving multi attribute decision making problems. GRA has been successfully applied in solving a variety of MADM problems. Deng (1989) proposed Grey Relational Analysis in the Grey Theory. GRA is a kind of impact evaluation model that can measure the degree of similarity or difference between two sequences based on their relation, which is called the Grey relational grade. If the alternative has the highest grey relational grade between the reference sequence and itself, then the alternative will be the 
best choice. GRA has been further developed and widely applied in many areas; some representative ones are: Introduction to Grey Systems (Liu \& Lin, 1998); Grey System Theory and Applications (Liu et al., 1999); Comparative Studies of using GRA in MADM Problems (Wu , 2002); Incidence Decision Making Models (Dang et al., 2004) ; GRA with Interval Numbers (Zhang et al., 2005); facility layout selection (Kuo et al., 2008); Supplier Selection (Wu, 2009); GRA with Intuitionistic Fuzzy Numbers (Wei, 2010); Energy Performance of Office Buildings (Lee \& Lin, 2011); Personnel Selection (Zhang \& Liu, 2011); Novel Models by using Visual Angle of Similarity (Liu et al., 2011); Novel Model Based on Grey Number Sequence (Liu \& Xie, 2011).

Fuzzy Multi Attribute Decision Making (FMADM): Decision Makers (DMs) preferred to give their judgements in linguistic form like 'low', 'average', 'high' etc (Prabhu \& Vizayakumar, 1996). There are attributes about which crisp performance scores cannot be assigned like 'quality', 'corrosion resistance', 'looks' etc. The classical MADM methods seem to be incapable of quantifying these judgements into crisp score. MADM methods remain silent about how to tackle this problem. If these attributes with linguistic terms are not quantified, they appear as unexplained variance in the decision making problem. Most of the real-world MADM problems are of mix type, containing crisp, fuzzy and/or linguistic performance attributes. It will be better to convert these linguistic values into fuzzy numbers for evaluation of technologies by using fuzzy multiple attribute decision methods (Chan, et al., 2001). To solve this problem fuzzy set theory to decision making problems was introduced by Bellman and Zadeh in 1970. Yager and Basson (1975) proposed fuzzy sets for decision making. But, the classical work to associate fuzzy set theory to MADM methods was done by Bass and Kwakernaak in 1977. Seeing the importance of the problem, number of researchers have proposed and reviewed several fuzzy MADM methods (Chen \& Hwang, 1992; Triantaphyllou \& Lin, 1996; Figueira et al., 2004). Some researchers have also applied FMADM methods in the field of advanced manufacturing technology like Perego and Rangone (1998) reviewed the use of FMADM for the selection of AMT; Abdel-Kader and Dugdale (2001) proposed a FMADM model for the evaluation of AMT, this model used the combination of AHP and fuzzy set theory to aggregate the financial and non-financial terms; Chhu (2009) applied fuzzy multiple group decision making with multiple fuzzy information for selection of advanced manufacturing technology, the model enables the decision makers to incorporate and aggregate fuzzy information. The models developed seem to be too complex and moreover, the different linguistic scales are ignored. A thorough review of the existing FMADM methods, clearly indicate that these methods are very complex and require too much cumbersome calculations. This problem becomes much more prevalent when alternatives and attributes are more than 10 (Rao, 2007). That drawback certainly limits their applicability to real-world problems. Chen and Hwang (1992) proposed an approach to solve MADM problems in a fuzzy environment. The approach is of two steps. In the first step, fuzzy data is converted into crisp scores. Then, as the next step, this data in the form of decision matrix is used to rank the alternatives by using MADM methods. In the following section, this method has been explained. This method logically converts linguistic terms into their corresponding fuzzy numbers through any of the eight conversion scales. These conversion scales are the extension of the work of Wenstop (1976), Bass and Kwakernaak (1977), Efstathiou and Rajkovic (1979), Bonissone (1982), Efstathiou and Tong (1982), Kerre (1982), and Chen (1988). These techniques can be applied to measure the effectiveness of manufacturing system even if the effectiveness factors have subjective nature. The nature of research on effectiveness or performance measurement of manufacturing systems is difficult to comprehend within the confines of any specific discipline, the relevant materials are scattered throughout numerous scholarly journals in various disciplines. Even with new search engines, the task of finding all the relevant articles is difficult and time consuming. Two excellent reviews of the literature can be found in Neely $(2000,2005)$. Raafat (2002) provided a comprehensive listing of articles on the justification of advanced manufacturing technologies. This paper brings together the wide-ranging work from a number of different disciplines and diverse with the published articles from 1990 to 2001 and provides a comprehensive bibliography on the subject. But it only targets the problem of justification, here in this paper authors have provided the comprehensive bibliography that covers every aspect of AMS effectiveness measurement and possible MADM techniques that can be 
used for measurement. The paper cites 265 articles from a variety of published sources mainly from 1990 to 2012 and a few additional published work prior to 1990. Every effort has been made to include the relevant paper. As paper title provides the sufficient information about the contents so no additional information has been provided as in Raafat (2002)'s.

\section{Concluding remarks}

The nature of research on effectiveness or performance measurement of manufacturing systems is difficult to comprehend within the confines of any specific discipline, the relevant materials are scattered throughout numerous scholarly journals in various disciplines. Even with new search engines, the task of finding all the relevant articles is difficult and time consuming. Two excellent reviews of the literature can be found in Neely $(2000,2005)$. Raafat (2002) provided a comprehensive listing of articles on the justification of advanced manufacturing technologies. This paper brings together the wide-ranging work from a number of different disciplines and diverse with the published articles from 1990 to 2001 and provides a comprehensive bibliography on the subject. However, it only targets the problem of justification, here in this paper authors have provided the comprehensive bibliography that covers every aspect of AMS effectiveness measurement and possible MADM techniques that can be used for measurement. The paper cites 265 articles from a variety of published sources mainly from 1990 to 2012 and a few additional published work prior to 1990. Every effort has been made to include the relevant paper. As paper title provides the sufficient information about the contents so no additional information has been provided as in Raafat (2002)'s. This paper will not only help the researchers in providing the bibliography of the matter concerned but also help them to understand the problem of manufacturing effectiveness measurement in a better way with possible solutions with the deployment of MADM approaches.

\section{Acknowledgement}

The thoughtful comments of the reviewers were extremely helpful in sharpening our ideas and we wish to acknowledge their constructive assistance.

\section{References}

Abdel-Kader, M. G., \& Dugdale, D. (2001). Evaluating investments in advanced manufacturing technology: A fuzzy set theory approach. British Accounting Review, 33(4), 455-489.

Agarwal, A., Shankar, R., \& Tiwari, M. K. (2007). Modeling agility of supply chain. Industrial Marketing Management, 36(4), 443-457.

Agarwal, D. (1997). An emprical investigation of the impact of advanced manufacturing technology on business performance. Ph.D Thesis, City University of New York, 248.

Agrawal, A., Shankar, R., \& Tiwari, M. K. (2006). Modeling the metrics of lean, agile and leagile supply chain: an ANP-based approach. European Journal of Operation Research, 173(1), 211-225.

Agrawal, V. P., Kohli, V., \& Gupta, S. (1991). Computer aided robot selection: the multi attribute decision making approach. International Journal of Production Research, 29(8), 1624-1644.

Attaran, M. (1989). The automated factory: Justification and implementation. Business Horizons, 32(3), 80-85.

Azzone, G., Masella, C., \& Bertele, U. (1991). Design of performance measures for time-based companies". International Journal of Operations \& Production Management, 11(3), 77-85.

Badiru, A. B. (1990). Strategic planning for advanced manufacturing: Some factors and dimensions. Justification Methods for Integrated Manufacturing Systems, Elsvier, New York, 17-39.

Baldwin, J., \& Diverty, B. (1995). Advanced Technology Use in Canadian Manufacturing Establishments. Canada: 24A, R.H. Coats Building, Ottawa, K1A 0T6.

Baldwin, J., \& Lin, Z. (2002). Impediments to advanced technology adoption for Canadian manufacturers. Research Policy, 31(1), 1-18. 
Bass, S. J., \& Kwakernaak, H. (1977). Rating and ranking of multi-aspects alternatives using fuzzy sets. Automatica, 13, 47-58.

Bayazit, O. (2005). Use of AHP in decision-making for flexible manufacturing systems. Journal of Manufacturing Technology Management, 16(7), 808-819.

Beatty, C. (1990). Implementing advanced manufacturing technology. Business Quarterly, 55(2), 4650.

Bellman, R. E., \& Zadeh, L. A. (1970). Decision-making in a fuzzy environment. Management Science, 17(4), 141-164.

Bernoulli, D. (1738). Specimen theoriae novae de mensura sortis. Commentarri Academiae Scientiarum Imperialis Petropolitanae, 5, 92-175.

Bessant, J., \& Haywood, B. (1986). Flexibility in manufacturing systems. Omega: The International Journal of Management Science, 14, 465-473.

Bhangle, P., Agrawal, V., \& Saha, S. (2004). Attribute based specification, comparison and selection of a robot. Mechanism and Machine Theory, 39, 1345-1366.

Blumberg, M., Silberman, S. J., \& Alber, A. (1982). The human element: Its impact on the advanced batch manufacturing systems. Journal of Manufacturing System, 1(1), 43-52.

Bonissone, P. P. (1982). A fuzzy sets based linguistic approach: Theory and Applications. In M. M. Gupta , \& E. Sanchez (Ed.), Approximate Reasoning in Decision Analysis, (pp. 329-339). North Holland.

Bowlin, W. F. (1987). Evaluating the efficiency of US air force real-property maintenance activities. Journal of Operation Research, 38, 127-135.

Boydell, T., Burgoyne, J., \& Pedler, M. (1991). The Learning Company: A Strategy for Sustainable Development. London: McGraw-Hill.

Boyer, K. K. (1994). Patterns of Advanced Manufacturing Technology Implementation: Technology and Infrastructure. The Ohio State University: Ph.D Thesis.

Boyer, K. K., Leong, G. K., Ward, P. T., \& Krajewsky, L. J. (1997). Unlocking the potential of advanced manufacturing technologies. Journal of Operation Management, 15(4), 331-347.

Boyer, K. K., Ward, P. T., \& Leong, G. K. (1996). Approaches to the factory of the future: An empirical taxnomy. Journal of Operation Management, 14, 297-313.

Bozdag , C. E., Kahraman, C., \& Ruan, D. (2003). Fuzzy group decision making for selection among computer integrated manufacturing systems. Computers in Industry, 51, 13-29.

Braglia, M., \& Petroni, A. (2010). Evaluating and selecting investments in industrial robots. International Journal of Production Research, 37(18), 4157-4178.

Brans, J. P., Mareschal, B., \& Vincke, P. (1984). PROMETHEE: A New Family of Outranking Methods in MCDM. IFORS'84, (pp. 477-490). North Holland.

Bromwich, M., \& Bhimani, A. (1991). Strategic investment appraisal. In Management Accounting ( 4548). US: Module Leader R. Lowbridge.

Brown, M. (1996). Keeping Score: Using the Right Metrics to Drive World Class Performance. New York: Quality Resources.

Browne, J., Dubois, D., Sethi, S. P., \& Stecke, K. E. (1984). Classification of Flexible Manufacturing Systems (April ed.). The FMS Magazine.

Burcher, P., Lee, G., \& Sohal, A. (1999). Lessons for implementing AMT. Some case experiences with $\mathrm{CNC}$ in Australia, Britain and Canada. International Journal of Operations and Production Management, 19, 515-526.

Burns, T., \& Stalker, G. M. (1961). The Management of Innovation. London: Tavi Stock.

Canada, J. R., \& Sullivan, W. G. (1989). Economic and Multiattribute Evaluation of Advanced Manufacturing Systems. Englewood Cliffs, NJ: Prentice Hall.

Canada, J. R., \& Sullivan, W. G. (1990). Persistent pitfalls and applicable approaches for justifiction of adavnced manufacturing systems. Engineering Costs and Production Economics, 18, 247-253.

Carnevale, A., \& Goldstein, H. (1990). Schooling and Training for Worker in America: An Overview. In L. Ferman, M. Hoyman, J. Cutcher-Gershenfeld, \& E. J. Savoie (Eds.), New Developments in Worker Training: A Legecy for the 1990s. Madison, WI: Industrial Relations Research Association. 
Celebi, D., Bayraktar, D., \& Bingöl, L. (2010). Analytical network process for logistics management: A case study in a small electronic appliances manufacturer. Computers \& Industrial Engineering, 58, 432-441.

Chan, F. S., Chan, M. H., Lau, H., \& Ip, R. L. (2001). Investment appriasal technique for advanced manufacturing technology (AMT): A Literature Review. Integrated Manufacturing Systems, 12(1), $35-47$.

Chan, F., Chan, M., Lau, H., \& Ip, R. (2001). Investment appriasal technique for advanced manufacturing technology (AMT): A Literature Review. Integrated Manufacturing Systems, 12(1), $35-47$.

Chandler, A. D. (1977). The Visible Hand- Managerial Revolution in American Business. Boston, MA: Harvard University Press.

Chen, I. J., \& Small, I. J. (1994). Implementing advanced manufacturing technology: An integrated planning model. International Journal of Mangement Science, 22(1), 91-103.

Chen, I. J., \& Small, M. H. (1996). Planning for advanced manufacturing technology: A research framework. International Journal of Operations \& Production Management, 16(5), 4-24.

Chen, S. J., \& Hwang, C. L. (1992). Fuzzy Multiple Attribute Decision Making Methods and Applications. New York: Springer.

Chen, S. M. (1988). A New Approach to Handling Fuzzy Decision-Making Problems. Proc. 18th International Symposium on Multiple-Valued Logic. Palma de Mallorca, Spain: Computer Society Press.

Chen, S., \& Hwang, C. (1992). Fuzzy Multiple Attribute Decision Making Methods and Applications. New York: Springer.

Chen, Y. W., \& Tzeng, G. H. (1999). A fuzzy multi-objective model for reconstructing post-earthquake road-network by genetic algorithm. nternational Journal of Fuzzy Systems, 1(2), 85-95.

Choobineh, F. (1986). Justification of Flexible Manufacturing Systems. In F. Choobineh, \& R. Suri (Eds.), Flexible Manufacturing Systems: Current Issues and Models (pp. 269-281). 2E Press.

Choquet, G. (1953). Theory of capacities. Annales de L'Institut Fourier, 5(1), 131-295.

Chu, T. C., \& Lin, Y. C. (2003). A fuzzy TOPSIS method for robot selection. International Journal of Advanced Manufacturing Technology, 21, 284-290.

Chung, S. H., Lee, A. H., \& Pearn, W. L. (2005). Analytic network process (ANP) approach for product mix planning in semiconductor fabricator. International Journal of Production Economics, 96(1), 15-36.

Chuu, S. J. (2009). Selecting the advanced manufacturing technology using fuzzy multiple attributes group decison making with multiple fuzzy information. Computers \& Industrial Engineering, 57(3), 1033-1042.

Co, H. C., Ptuwo, B. E., \& Hu, M. Y. (1998). The human factors in advanced manufacturing technology adoption: An empirical analysis. International Journal of Operations and Production Management, 18(1), 87-106.

Costa, S. E., \& Lima, E. P. (2009). Advanced manufacturing technology adoption:an integrated approach. Journal of Manufacturing Technology Management, 20(1), 74-96.

Dang, Y. G., Liu, S. F., Liu, B., \& Yu, Y. W. (2004). Study on incidence decision making model of multi-attribute interval number. Journal of Nanjing University of Aeronautics and Astronautics, 36(3), 403-406.

Dangayach, G. S., \& Deshmukh, S. G. (2005). Advanced manufacturing technology implementation: Evidence from Indian small and medium enterprises (SMEs). Journal of Manufacturing Technology Management, 16(5), 483-496.

Dangayach, G., \& Deshmukh, S. (2004). Advanced manufacturing technologies: Evidences from Indian automobile companies. International Journal of Manufacturing Technology and Management, 6(5), 426-433.

Dangayach, G., \& Deshmukh, S. G. (2003). Evidence of manufacturing strategies in Indian industry. International Journal of Production Economics, 83, 279-298. 
Datta, V., Sambasivarao, K., Kodali, R., \& Deshmukh, S. (1992). Multi attribute decision making model using the analytic hierarchy process for the justification of manufacturing systems. International Journal of Production Economics, 28, 227-234.

David, F., Pearce II, J. A., \& Randolph, W. A. (1989). Linking technology and structure to enhance group performance. Journal of Applied Psychology, 74(2), 233-241.

David, L., Hitt, M. A., \& Goldhar, J. D. (1996). Advanced manufacturing technology: Organisational design and strtegic flexibility. Organisation Studies, 17, 501-523.

Dean, J. W., Susman, G. I., \& Porter, P. S. (1990). Technical, economic and political factors in advanced maufcaturing technology implementation. Journal of Engineeirng, Technology and Management, 7, 129-144.

Deng, J. (1982). Control problem of grey systems. Systems and Control Letters, 1(5), 288-294.

Deng, J. L. (1989). The introduction to grey system theory. The Journal of Grey System, 1(1), 1-24.

Diaz, M. S., Machucaa, J., \& Alvarez-Gil, M. (2003). A view of developing patterns of investment in AMT through empirical taxonomies: New evidence. Journal of Operation Management, 21, $577-$ 606.

Dimnik, T. P., \& Johnston, D. A. (1993). Manufacturing managers and adoption of advanced manufacturing technology. Omega: International Journal of Management Science, 21(2), 155-162.

Dou, J., Dai, X., \& Meng, Z. (2009). Graph theory based approach to optimize single-product flow-line configurations of RMS. International Journal of Advanced Manufacturing Technology, 41(9/10), 916-931.

Drucker, P. (1988). Technology, Management and Society. New York: Harper \& Row.

Drury, C. (1990). Counting the cost of AMT investment (Part 1). Accountancy, 105(1160), 134-138.

Efstathiades, A., Tassou, S., Antoniou, A., \& Oxinos, G. (1999). Strategic considerations in the introduction of advanced manufacturing technology in the cypriot industry. Technovation, 15, 105115.

Efstathiou, J., \& Rajkovic, V. (1979). Multiattribute decision making using a fuzzy heuristic approach. IEEE Transactions on Systems, Man, Cybernetics, 9, 326-333.

Efstathiou, J., \& Tong, R. (1980). Ranking Fuzzy Sets using Linguistic Preference Relations. Proc. 10th International Symposium on Multiple-Valued Logic. Northwestern University,Evanston.

Ferdows, K., \& De Meyer, A. (1990). Lasting improvements in manufacturing performance: In Search of New Theory. Journal of Operation Management, 9, 168-184.

Figueira, J., Greco, S., \& Ehrgott, M. (2004). Multiple Criteria Decision Analysis: State of the Art Surveys. New York: Springer.

Fitzgerald, L., Johnston, R., Brignall, S., Silvestro, R., \& Voss, C. (1991). Performance Measurement in Service Business. London: CIMA.

Frohlich, M. (1998). How do you successfully adopt an advanced manufacturing technology? European Management Journal, 16(2), 151-159.

Fulton, M., \& Hon, B. (2010). Managing advanced manufacturing technology (AMT) implementation in manufcaturing SMEs. International Journal of Productivity and Peformance Management, 59(4), 351-371.

Gandhi, O., \& Agrawal, V. (1996). Failure cause analysis- A structural approach. Journal of Pressure Vessel Technology, 118(4), 434-439.

Garetti, S. E. (1986). Stategy First: A Case in FMS Justification. In R. Suri (Ed.), Proceedings of the second ORSA/TIMS Conference on Flexible Manufacturing Systems, Operation Research Models and Applications (pp. 17-29). Ann Arbor, MI, U.S.A.: University of Michigan.

Garside, J. (1999). Make it! Engineering the Manufacturing Solution. Woburn, MA: ButterworthHeinemann Publishing Ltd.

Ghalayini, A. M., Noble, J. S., \& Crowe, T. J. (1997). An integrated dynamic performance measurement system for improving manufacturing competitiveness. International Journal of Production Economics, 48(3), 207-225.

Ghani, K. A., \& Jayabalan, V. (2000). The journal of high technology management research. Advanced Manufacturing Technology and Planned Organisational Change, 11(1), 1-18. 
Ghani, K., Jayabalan, V., \& Sugumar, M. (2002). Impact of advanced manufacturing technology on organisational structure. The Journal of High Technology Management Research, 13(2), 157-175.

Godwin, J., Ehie, I., \& Oluruniwo, F. (1995). Fulfilling the promises of advanced manufacturing systems. Industrial Management, 37(5), 23-28.

Golec, A., \& Taskin, H. (2007). Novel Methodologies and a comparative study for manufacturing systems performance evaluations. Information Sciences, 177(23), 5253-5274.

Greshwin, S. B. (1994). Manufacturing Systems Engineering. Englewood Cliffs, NJ: Prentice-Hall.

Greshwin, S. B. (2000). Design and operation of manufacturing systems: the control-point policy. IIE Transactions, 32, 891-906.

Grover, S., Agrawal, V., \& Khan, I. (2004). A digraph approach to TQM evaluation of an industry. International Journal of Production Research, 42(19), 4031-4053.

Grover, S., Agrawal, V., \& Khan, I. (2006). Role of human factors in TQM: A graph theoretic approach. International Journal of Benchmarking, 13(4), 447-468.

Gunawardana, K. (2006). Introduction of advanced manufacturing technology: A lierature review. Sabaragamuwa University Journal, 6(1), 116-134.

Hayes, R. H., \& Wheelwright, S. C. (1984). Restoring Our Competitive Edge: Competing Through Manufacturing. New York: John Wiley.

Hirschhorn , L. (1984). Beyond Mechanization: Work and Technology in Post Industrial Age. Cambridge, MA: MIT Press.

Hon, K. K. (2005). Performance and evaluation of manufacturing systems. CIRP AnnalsManufacturing Technology, 54(2), 139-154.

Hsia, K. H., Chen, M. Y., \& Chang, M. C. (2004). Comments on data Pre-processing for grey relational analysis. Journal of Grey System, 7(1), 15-20.

Huang, Z., \& Yip-Hoi, D. (2003). A graph based approach for capturing the capability envelop of a machining process. International Journal of Mnaufacturing Science and Engineering, 125(2), 272288.

Hwang, C. L., \& Yoon, K. (1981). Multiple Attribute Decision Making, Methods and Applications. Now York: Springer-Verlag.

Hwang, M. J., Tzeng, G. H., \& Liu, Y. H. (1996). A dynamic model for optimal expansion of multistage competence sets. Journal of Management, 14(1), 115-133.

Hynek, J., \& Janeček, V. (2007). Justification of investment into advanced manufacturing Ttechnology. International Journal of Circuits, Systems and Signal Processing, 3(1), 282-288.

Jain, S., Triantis, K. P., \& Liu, S. (2011). Manufacturing performance measurement and target setting: A data envelopment analysis approach. European Journal of Operational Research, 214(3), 616626.

Jharkharia, S., \& Shankar, R. (2005). IT-enablement of supply chains: Understanding the barriers. The Journal of Enterprise Information Management, 18(1), 11-27.

Jimenez, J., Martinez, A., Navarro, L., Polo, Y., \& Tomas, L. (1992). The process of implementing industrial robots in spanish industry. Internationak Journal of Operations and Production Management, 12, 43-56.

Johnson, H. T., \& Broms, A. (2000). Profit Beyond Measure: Extraordinary Results Through Attention to Work and People. Free Press.

Kaplan, R. S. (1986, April). Must CIM be justified by faith alone. Harvard Business Review, pp. 87-95.

Kaplan, R. S., \& Norton, D. P. (1992, January-February). The balanced scorecard - measures that drive perfromance. Harvard Business Review, 9-71.

Karim, M., Smith, A., Halgamuge, S., \& Islam, M. (2008). A comparative study of manufacturing practices and performance variables. International Journal of Production Economics, 112(2), 841859.

Karpak, B., \& Topcu, I. (2010). Small medium manufacturing enterprises in Turkey: Ananalytic network process framework for prioritizing factors affecting success . International Journal of Production Economics, 125(1), 60-70. 
Karsak, E. E. (2010). Distance based fuzzy MCDM approach for evaluating flexible manufacturing system alternatives. International Journal of Production Research, 40(13), 3167-3181.

Karsak, E. E., \& Kuzgunkaya, O. (2002). A fuzzy multiple objective programming approach for the selection of a fexible manufacturing system. International Journal of Production Economics, 79, 101-111.

Karsak, E., \& Tolga, E. (2001). Fuzzy multi-criteria decision making procedure for evaluating advanced manufacturing system investments. International Journal of Production Economics, 69(1), 49-64.

Keegan, D. P., Eiler, R. G., \& Jones, C. R. (1989, June). "Are your performance measures obsolete?". 45-50.

Keeney, R. L., \& Raiffa, H. (1976). Decision with Multiple Objectives: Preferences and Value Tradeoffs. New York: John Wiley and Sons.

Kerre, E. E. (n.d.). The Use of Fuzzy Set Theory in Electrocardiological Diagnostics. In M. M. Gupta, \& E. Sanchez (Ed.), Approximate Reasoning in Decision Analysis, (pp. 277-282). North Holland.

Khouja, M. (1995). The use of data envelopment analysis for technology selection. Computers in Industrial Engineering, 28(1), 123-132.

King, N., \& Majchrzak, A. (1996). Concurrent engineering tools: Are the human issues being ignored? IEEE Transactions on Engineering Management, 43, 189-201.

Kotha, S., \& Swamidass, P. M. (2000). Strategy, advanced manufacturing technology and performance: empirical evidence from U.S. manufacturing firms. Journal of Operations Management, 18, 257277.

Kueng, P. (2000). Process performance measurement system: a tool to support process-based organizations. Total Quality Management, 11(1), 67-85.

Kulkarni, S. (2005). Graph theory and matrix approach for performance evaluation of TQM in Indian industries. International Journal of TQM in Indian Industries, 17(6), 509-526.

Kumar, R., \& Garg, R. K. (2010). Optimal selection of robots by using distance based approach method. Robotics andComputer-Integrated Manufacturing, 26, 500-506.

Kumar, V., Murphy, S. A., \& Loo, S. K. (1996). An investment decision process: The case of advanced technologies in Canadian manufacturing firms. International Journal of Production Research, 34(4), 947-958.

Kunnathar, A. (2000). Factors affecting the adoption of advanced manufacturing technology in small firms. Advanced Management Journal, 65(2), 14-23.

Kuo, Y., Yang, T., \& Huang, G. W. (2008). The use of grey relational analysis in solving multiple attribute decision-making problems. Computer \& Industrial Engineering, 55(1), 80-93.

Lang, T. -M., Chiang, J. -H., \& Lan, L. W. (2009). Selection of optimal supplier in supply chain management strategy with analytic network process and Choquet integral. Computers \& Industrial Engineering, 57(1), 330-340.

Lee, A. H., Chen, W. C., \& Chang, C. J. (2007). A Fuzzy AHP and BSC approach for evaluating performance of IT department in the manufacturing industry in Taiwan. Expert Systems with Applications, 34(1), 96-107.

Lee, W. S., \& Lin, Y. C. (2011). Evaluating and ranking energy performance of office buildings using grey relational analysis. Energy, 36(5), 2551-2556.

Leong, G. K., Synder, D. L., \& Ward, P. T. (1990). Research in the process and content of manufacturing strategy. Omega, 18(2), 109-122.

Lewis, H. J., Towill, D. R., \& Davies, A. (1988). The introduction of AMT - Triumph or Trauma. (D. R. Towill, \& J. E. Cherringlon, Eds.) London: Springer-Verlag.

Liu, S. F., \& Lin, Y. (1998). An Introduction to Grey Systems: Foundations, Methodology and Applications. 120-155.

Liu, S. F., \& Xie, N. M. (2011). A novel grey relational model based on grey number sequences. Grey Systems: Theory and Application, 1(2), 117-128.

Liu, S. F., Guo, T. B., \& Dang, Y. G. (1999). Grey System Theory and its Application. ${ }^{\text {nd }}$ ed., Beijing: Science Press. 
Liu, S. F., Xie, N. M., \& Forrest, J. (2011). Novel models of grey relational analysis based on visual angle of similarity and nearness. Grey Systems: Theory and Application, 1(1), 8-18.

Liu, S. -T. (2008). A fuzzy DEA/AR approach to the selection of flexible manufacturing systems. Computers \& Industrial Engineering, 54, 66-76.

Luong, L. H. (1998). A decision support system for the selection of computer-integrated manufacturing technologies. Robotics and Computer-Integrated Manufacturing, 14, 45-53.

Lynch, R. L., \& Cross, K. F. (1991). Measure Up- the Essential Guide to Measuring Business. London: Mandarin.

Machuca, J. A., Diaz, M. S., \& Gil, M. J. (2004). Adopting and implementing advanced manufacturing technology: New data on key factors from the aeronautical industry. International Journal of Production Research, 42(16), 3183-3202.

Maffei, M., \& Meredith, J. (1994). The organisational side of flexible manufacturing technology. International Journal of Operation \& Production Management, 14(8), 17-34.

Malhotra, M., \& Grover, V. (1998). An assessment of survey research in POM: from constructs to theory. Journal of Operation Management, 16(4), 407-425.

Marcus, M., \& Minc, H. (1965). Permanents. American Mathematics Monthly, 72, 571-591.

Marri, H. B., Irani, Z., \& Gunasekran, A. (2006). A framework of justification criteria for advanced manufacturing technology implementation in small and medium enterprises. European and Mediterranean Conference on Information Systems (EMCIS). Costa Blanca, Alicante, Spain.

McDermott, C. M., \& Stock, G. (1999). Organisational culture and advanced manufacturing technology implementation. Journal of Operation Management, 17(5), 521-533.

Meade, L. M., \& Sarkis , J. (1999). Analyzing organizational project alternatives for agile manufacturing processes-ananalytical network approach. International Journal of Production Research, 37(2), 241-261.

Meredith, J., \& Hill, M. (1990). Justifying New Manufacturing Systems: A Managerial Approach. In A. Boynton, \& R. Zmud (Eds.), Management Information Systems (pp. 370-387). Glenview, Illinois, USA: Scott, Foresman \& Co.

Meredith, J., \& McTevish, R. (1992). Organized manufacturing for superior market performance. Long Range Planning, 25(6), 63-71.

Meredith, J., \& Suresh, N. (1986). Justification techniques for advanced manufacturing technologies. International Journal of Production Research, 24(5), 1043-1057.

Mital, A. P. (1999). The need for worker training in advanced manufacturing technology (AMT) environments: A white paper. International Journal of Industrial Ergonomics, 24, 173-184.

Mohanty, R. P., \& Deshmukh, S. G. (1998). Advanced manufacturing technology selection:A strategic model for learning and evaluation. International Journal of Production Economics, 55(3), 295-307.

Monge, C., Rao, S., Gonzalez, M., \& Sohal, A. (2006). Performace measurement of AMT: A crossregional study. Benchmarking: An International Journal, 13(1/2), 135-146.

Naik, B., \& Chakravarthy, A. (1992). Strategic acquisition of new manufacturing technology: A review and research framework. International Journal of Production Reseach, 30(7), 1575-1601.

Narain, R., Yadav, R., \& Antony, J. (2004). Productivity Gains from Flexible Manufacturing: Experiences from India. International Journal of Productivity and Performance Management, 53(2), 109-128.

Narsingh, D. (2000). Graph Theory with Application to Engineering and Computer Science. Delhi: Prentice Hall of India Private Ltd.

Nasim, S. (2011). Total interpretive structural modeling of continuity and change forces in egovernment. Journal of Enterprise Transformation, 1(2), 147-168.

Neely, A. D. (1998). Measuring Business Performance. London: Economist Books.

Neely, A., Gregory, M., \& Platts, K. (2005). Performance measurement system design-A literature review and research agenda. International Journal of Operations \& Production Management, 25(12), 1228-1263. 
Neely, A., Mills, J., Platts, K., Richards, H., Gregory, M., Bourne, M., et al. (2000). Performance measurement system design: Developing and testing a process-based Approach. International Journal of Operations \& Production Management, 20(10), 1119-1145.

Nemetz, P., \& Fry, L. (1988). Flexible manufacturing organisations: Implications for strategy formulation and organisational design. Academy of Management Review, 13, 627-638.

Neumann, V. J., \& Morgenstern, O. (1947). Theory of Games and Economic Behavior (2nd ed.). Princeton, New Jessie: Princeton University Press.

Opricovic, S. (1998). Multicriteria optimization of civil engineering systems. Belgrade: Faculty of Pennsylvania.

Ordoobadi, S. M., \& Mulvaney, N. J. (2001). Development of a justification tool for advanced manufacturing technologies: System-wide benefits value analysis. Journal of Engineering Technology and Mangement, 18, 157-184.

Oztaysi, B., Kaya, T., \& Kahraman, C. (2011). Performance comparison based on customer relationship management using analytic network process. Expert Systems with Application, 38, 9788-9798.

Pagell, M., Hanfield, R. D., \& Barber, A. E. (2000). Effects of operational employee skills on advanced manufacturing technology performance. Production and Operations Management, 9(3), 222-238.

Parthasarathy, R., \& Sethi, S. P. (1990). The Impact of Flexible Automation on Business Strategy and Organisational Structure. Fairleigh Dickinson University.

Parthasarthy, R., \& Sethi, S. (1992). The impact of flexible automation on business strategy and organizational structure. Academy of Management Review, 17(1), 86-111.

Pawlak, Z. (1982). Rough Sets. International Journal of Man-Machine Studies, 20(5), 341-356.

Pawlak, Z., \& Slowinski, R. (1994). Rough set approach to multi-attribute decision analysis. European Journal of Operation Research, 72, 443-459.

Percival, J. (2004). Complementarities in the implementation of advanced manufacturing technologies. In Ph.D Thesis. Canada: University of Waterloo.

Perego, A., \& Rangone, A. (1998). A reference framework for the application of MADM fuzzy techniques for selecting AMTS. International Journal of Production Research, 36(2), 437-458.

Pham, D. T., \& Yeo, S. H. (1988). A knowledge-based system for robot gripper selection: Criteria for choosing grippers and surfaces for gripping. International Journal of Machine Tool and Manufacture, 28(4), 301-313.

Porter, M. (1996). What is Strategy? Harvard Business Review, 74(6), 61-78.

Prabhu, T., \& Vizayakumar, K. (1996). Fuzzy hierarchical decison making (FHDM): A methodology for technology choice. International Journal of Computer Applications in Technology, 9, 322-329.

Primrose, P. L. (1991). Investment in Manufacturing Technology. London: Chapman \& Hall.

Raafat, F. (2002). A comprehensive bibliography on justification of advanced manufacturing systems. International Journal of Production Economics, 79, 197-208.

Rahman, A. (2008). Buyer-supplier relationships in advanced manufacturing technology acquisition and implementation in Malaysia. International Journal of Economics and Management, 2(1), 95126.

Raj, T., Shankar, R., \& Suhaib, M. (2007). A review of some issues and identification of some barriers in the implementation of FMS. International Journal of Flexible Manufacturing Systems, 19, 1-40.

Raj, T., Shankar, R., \& Suhaib, M. (2008). An ISM approach for modeling the enablers of flexible manufacturing system: the case for India. International Journal of Production Research, 46(24), 6883-6912.

Raj, T., Shankar, R., Suhaib, M., \& Khan, R. A. (2010). A Graph-theoretic approach to evaluate the intensity of barriers in the implementation of FMSs. International Journal of Services and Operations Management, 7(1), 24-52.

Ramamurthy, K. (1995). Influence of planning on implementation success of AMT. IEEE Transactions on Engineering Management, 42(1), 62-73.

Rao, R. V. (2007). Decision Making in the Manufacturing Enviornment using Graph Theory and Fuzzy Multi Atribute Dcison Making Methods. London: Springer-Verlag. 
Rao, R., \& Gandhi, O. (2002). Digraph and matrix methods for the machinability evaluation of work materials. International Journal of Machine Tools and Manufacture, 42, 321-330.

Rao, V., \& Padmanabhan, K. (2006). Selection, identification and comparison of industrial robots using digraph and matrix methods. International Journal of Robotics and Computer Integrated manufacturing, 22(4), 373-383.

Reinsch, S., Müsig, B., Schmidt, B., \& Tracht, K. (2003). Advanced manufacturing systems for forging products. Journal of Materials Processing Technology, 138, 16-21.

Roth, A., Gaimon, C., \& Krajewski, L. (1991). Optimal acquisition of FMS technology subject to technological progress. Decision Sciences, 22(2), 308-334.

Roy, B. (1968). Classement et choix en presence de points de vue multiples (la methode Electre). revue Francaise d'Informatique et de Recherche Operationnelle, 8(1), 57-75.

Roy, B. (1971). Problems and methods with multiple objective functions. Mathematical Programming, 1(1), 239-266.

Roy, B. (1976). From Optimization to Multicriteria Decision Aid: Three Main Operational Attitudes In Multiple Criteria Decision Making. In H. Zionts, \& T. S. (Ed.). 130, pp. 1-34. Berlin: SpringerVerlag.

Roy, B. (1978). ELECTRE III: Un Algorithme de Classements Fondé sur une Représentation floue des Préférences en Présence de Critéres Multiples. Cahiers du Centre d'Etudes de Recherche Opérationnelle, 20, 3-24.

Sa' nchez, M. A. (1996). Adopting AMT: Experience from Spain. Journal of Mnaufacturing Systems, 15, 133-140.

Saaty, T. L. (1972). An Eigenvalue Allocation Model for Prioritization and Planning. University of Pennsylvania.

Saaty, T. L. (1980a). The Analytic Hierarchy Process-Planning, Priority Setting, Resource. New York: Mc-Graw Hill.

Saaty, T. L. (1980b). The Analytic Hierarchy Process. New York: Mc-Graw Hill Book Co.

Saaty, T. L. (1992). A natural way to make momenents decision. Journal of Science and Industrial Research, 61, 561-571.

Saaty, T. L. (1996). Decision Making with Dependence and Feedback: The Analytic Network Process. Pittsburgh: RWS Publications.

Saaty, T. L. (2005). Theory and Applications of the Analytic Network Process. Pittsburgh: RWS Publications.

Saberi, S., Yusuff, R., Zulkifli, N., \& Ahmad, M. (2010). Effective factors on advanced manufacturing technology implementation performance: A Review. International Journal of Applied Science, 10(13), 1229-1242.

Sage, A. (1977). Interpretive Structural Modeling: Methodology for Large-scale Systems. New York,NY: McGraw-Hill.

Sakawa, M. (1984). Interactive fuzzy goal programming for multiobjective nonlinear programming problems and its application to water quality management. Control and Cybernetics, 13(3), 217-228.

Sambasivarao, K. V., \& Deshmukh, S. G. (1994). Startegic framework for implementing flexible manufacturing systems in India. International Journal of Operations and Production Management, 14(4), 50-63.

Sambasivarao, K., \& Deshmukh, S. (1995). Selection and implementation of advanced manufacturing technologies: Classification and literature review of issues. International Journal of Operations \& Production Management, 15(10), 43-62.

Sambasivarao, K., \& Deshmukh, S. (1997). A decision support system for selection and justification of advanced manufacturing technologies. Production Planning and Control, 8(3), 270-284.

Saraph, J., \& Sebastian, R. (1992). Human resource strategies for effective introduction of advanced manufacturing technologies (AMT). Production \& Inventory Management Journal, 33(1), 64-70.

Sarkis, J. (1997). Evaluating flexible manufacturing systems alternatives using data envelopment analysis. The Engineering Economist, 43(1), 25-47. 
Saxena, J., Sushil, \& Vrat, P. (2006). Policy and strategy formulation: An application of flexible systems methodology. GIFT Publishing, Global Institute of Flexible Systems Management, New Delhi.

Schroder, R., \& Sohal, A. (1999). Organizational characteristics associated with AMT adoption; Towards a contingency framework. International Journal of Operations and Production Management, 19(12), 1270-1291.

Shang, J., \& Sueyoshi, T. (1995). A unified framework for the selection of a flexible manufacturing system. European Journal of Operational Research, 85, 297-315.

Shani, A. B., Grant, R. M., Krishnan, R., \& Thompson, E. (1992). Advanced manufacturing systems and organisational choice. California Management Review, 34, 91-111.

Sheu, D. D., \& Peng, S. L. (2003). Assessing manufacturing management performance for notebook computer plants in Taiwan. International Journal of Production Economics, 84, 215-228.

Shi, K. (1990). Grey Relational Theory and its Applications. ISUMA90.

Singh, M., Shankar, R., Narain, R., \& Agarwal, A. (2003). An interpretive structural modeling of knowledge management in engineering industry. Journal of Advances in Management Research, $1(1), 28-40$.

Singh, R. K., Garg, S. K., Deshmukh, S. G., \& Kumar, M. (2007). Modelling of critical success factors for implementation of AMTs. Journal of Modelling in Management, 2(3), 232-250.

Slack, N. (1991). The Manufacturing Advantage: Achieving Competitive Manufacturing Operations. London: Mercury.

Slagmulder, R., \& Bruggeman, W. (1992). Investment justification of flexible manufacturing technologies: Inferences from field research. International Journal of Production Management, 12(7/8), 168-186.

Small, M. H. (2006). Justifying investment in adavanced manufacturing technology: A portfolio analysis. Industrial Management and Data Systems, 106(4), 485-508.

Small, M. H., \& Chen, I. J. (1995). Investment justification of advanced manufacturing technology: An empirical analysis. Journal of Engineering and Technology Management, 12(1/2), 27-55.

Small, M. H., \& Yasin, M. M. (1997). Advanced manufacturing technology: Implementation policy and performance. Journal of Operation Management, 15(4), 349-370.

Small, M. H., \& Yasin, M. M. (2003). Advanced manufacturing technology adoption and performance: the role of management information systems departments. Integrated manufacturin Systems, 14, 409-422.

Small, M., \& Chen, I. (1995). Investment justification of advanced manufacturing technology: An empirical analysis. Journal of Engineering and Technology Management, 12(1/2), 27-55.

Sohal, A. (1996). Assessing AMT implementations: an empirical field study. Technovation, 16, 383399.

Sohal, A. S., Schroder, R., Uliana, E. O., \& Maguire, W. (2001). Adoption of AMT by South African manufacturers. Integrated Manufacturing Systems, 12(1), 15-34.

Stainer, A., Ghobadian, A., Liu, J., \& Stainer, L. (1996). Strategic investment appraisal for advanced manufacturing technology. International Journal of Materials and Product Technology, 11(1/2), 7688.

Stock, G., \& Tatikonda, M. (2000). A typology of project-level technology transfer processes. Journal of Operations Management, 18, 719-737.

Strang, G. (1980). Linear Algebra and its Applications. Harcourt Brace Jovanovich.

Sugeno, M. (1974). Theory of fuzzy integrals and its applications. In Ph.D Dissertation. Tokyo, Japan: Tokyo Institute of Technology.

Sullivan, W. G. (1991). A new paradigm for engineering economy. The Engineering Economist, 36(3), $187-200$.

Sushil. (2005). Interpretive matrix: A tool to aid interpretation of management and social research. Global Journal of Flexible Systems Management, 6(2), 27-30.

Sushil. (2011). Interpreting the Interpretive Structural Model. Working Paper, DMS, IITD. 
SVIOKLA, J. J. (1996). Knowledge workers and radically new technology. Sloan Management Review, 37, 25-40.

Tabucanon, M. T., Batanov, D. N., \& Verma, D. K. (1994). Decision support system for multicriteria machine selection for flexible manufacturing systems. Computers in Industry, 25, 131-143.

Talluri, S., \& Sarkis, J. (2002). A methodology for monitoring system performance. International Journal of Production Research, 40(7), 1567-1582.

Tan, K. H., \& Platts, K. (2004). Operationalising strategy: Mapping manufacturing variables. International Journal of Production Economics, 89, 379-393.

Tangen, S. (2003). An overview of frequently used performance measures. Work Study, 52(7), 347354.

Thomas , A. J., Braton, R., \& John, E. G. (2007). Advanced manufacturing technology implementation, A review of benefits and a model for change. International Journal of Productivity and Performance Management, 57(2), 156-176.

Thomas, A., \& Grabot, B. (2006). Key technologies and strategies for creating sustainable manufacturing organisations. Intelligent Production Machines and Systems, 614-619.

Tracey, M., Vonderembse, M., \& Lim, J. (1999). Manufacturing technology and strategy formulation: Keys to enhancing competitiveness and improving performance. Journal of Operations Management, 17(4), 411-428.

Triantaphyllou, E., \& Lin, C. T. (1996). Development and evaluation of five fuzzy multi attribute decision making methods. International Journal of Approximate Reasoning, 14, 281-310.

Tzeng, G. H., \& Huang, J. J. (2011). Multi Attribute Decision Making-Methods and Applications. Boca Raton, FL: CRC Press.

Tzeng, G. H., Hwang, M. J., \& Liu, Y. H. (1997). Dynamic optimal expansion for fuzzy competence sets of multistage-multi-objective planning. Pan Pacific Management Review, 1(1), 55-70.

Udo, G., \& Ebiefung, A. (1999). Human factors affecting the success of advanced manufacturing systems. Computer \& Industrial Engineering, 37(1-2), 297-300.

Udo, G., \& Ehie, I. (1996). Advanced manufacturing technologies-determinants of implementation success. International Journal of Operations and Production Management, 16(12), 6-26.

Upton, D. (1994). The management of manufacturing flexibility. California Management Review, $72-$ 89.

Ustun, O., \& Demirtas, E. -A. (2009). Analytic network process and multi-period goal programming integration in purchasing decisions. Computer \& Industrial Engineering, 56, 677-690.

Vinodh, S., Ramiya, R. A., \& Gautham, S. G. (2011). Application of fuzzy analytic network process for supplier selection in a manufacturing organisation. Expert Systems with Applications, 38, 272280.

Voss, C. A. (1988). Implementation: A key issue in manufacturing technology: the need for a field of study. Research Policy, 17, 55-63.

Wang, W. K., Huang, H. C., \& Lai, M. C. (2008). Design of a knowledge-based performance evaluation system: A case of high-tech state-owned enterprises in an emerging economy. Expert Systems with Applications, 37(3), 1795-1803.

Wang, Y. M., \& Chin, K. S. (2009). A new approach for the selection of advanced manufacturing technologies: DEA with double frontiers. International Journal of Production Research, 47(23), 6663-6679.

Wani, M., \& Gandhi , O. (1999). Development of Maintainability Index for Mechanical Systems. Reliability Engineering and System Safety, 65(3), 259-270.

Warfield, J. (1973, April). An Assault on Complexity. Battelle Monograph, 3.

Warfield, J. (1999). Twenty laws of complexity: Science applicable in organizations. Systems Research and Behavioral Science, 16(1), 3-40.

Warfield, J., \& Cárdenas, A. (1994). A Handbook of Interactive Management. Ames, IA: The Iowa State University Press.

Wei, G. W. (2010). GRA method for multiple attribute decision making with incomplete weight information in intuitionistic fuzzy setting. Knowledge Based Systems, 23, 243-247. 
Wenstop, F. (1976). Fuzzy set simulation models in a systems dynamic perspective. Kybernetes, 6, 209-218.

Wheelwright, S. C., \& Hayes, R. H. (1985, Jan-Feb). Competing Throgh Manufacturing. Harvard Business Review, 99-109.

Wisner, J. D., \& Fawcett, S. E. (1991). Link firm strategy to operating decisions through performance measurement. Production and Inventory Management Journal, Third Quarter, 5-11.

Woodward, J. (1965). Industrial Organization: Theory and Practice. London: Oxford University Press.

Wu, D. S. (2009). Supplier selection in a fuzzy group setting: A method using grey related analysis and Dempster-Shafer theory. Expert Systems with Applications, 36(5), 8892-8999.

$\mathrm{Wu}, \mathrm{H}$. H. (1996). The Introduction of Grey Analysis. Taipei: Gauli Publishing Co.

$\mathrm{Wu}, \mathrm{H}$. H. (2002). A comparative study of using grey relational analysis in multiple attribute decision making problems. Quality Engineering, 15(2), 209-217.

Yang, C. L., Chuang, S. P., \& Huang, R. W. (2009). Manufacturing evaluation system based on AHP/ANP approach for wafer fabricating industry. Expert Systems with Applications, 36(8), 1136911377.

Yeung, C. (2008). Strategic supply management, Quality Initiatives and Organizational Performance. Journal of Operations Management, 26(4), 490-502.

Yurdakul, M. (2002). Measuring a manufacturing system's performance using Saaty's system with feedback approach. Integrated Manufacturing Systems, 13(1), 25-34.

Yurdakul, M. (2004). Selection of computer integrated manufacturing technologies using a combined analytic hierarchy process and goal programming model. Robotics and Computer-Integrated Manufacturing, 20, 329-340.

Yusuff, R. M., Yee, K. P., \& Hashmi, M. J. (2001). A preliminary study on the potential use of the analytical hierarchical process (AHP) to predict advanced manufacturing technology (AMT) implementation. Robotics and Computer Integrated Manufacturing, 17, 421-427.

Yusuff, R., Ahmad, M., \& Osman, M. (2004). Barriers to AMT implementation in the SMEs of a developing country. International Journal of Engineering Technology, 1, 39-46.

Zadeh, L. (1965). Fuzzy sets. Information \& Conrtrol, 8(3), 338-353.

Zairi, M. (1993). Competitive manufacturing; Combining total quality management with advanced technology. Long Range Planning, 26(3), 123-132.

Zairi, M. (1998). Supplier partnerships for effective advanced manufacturing technology implementation: A proposed model. Integrated Manufacturing Systems, 9, 109-119.

Zammuto, R., \& O'Connor, E. (1992). Gaining advanced manufacturing technologies' benefits: The roles of organization design and culture. The Academy of Management Review, 17(4), 701-728.

Zhang, J. J., Wu, D. S., \& Olson, D. L. (2005). The method of grey relational analysis to multiple attribute decision making problems with interval numbers. Mathematical and Compter Modelling, 42, 991-998.

Zhang, S. F., \& Liu, S. Y. (2011). A GRA-based intuitionistic fuzzy multi-criteria group decision making method for personnel selection. Expert Systems with Applications, 38(9), 11401-11405.

Zhao, H., \& Co, H. (1997). Adoption and implementation of advanced manufacturing technology in Singapore. International Journal of Production Economics, 48(1), 7-19. 